\title{
Neo-kantianism and Neo-hegelianism. Comments on Neo-philosophy
}

The questions that arise when one attempts to define the relationship between neo-kantianism and neo-hegelianism may be formulated as follows: are we speaking of two parallel "neo-philosophies", or is the common prefix insufficient for us to speak of a simple analogy between them. In the latter case, it would be necessary to examine the entire set of differences between the two neo-philosophies in order to find their reference to a philosopher analysed and the significance of their achievements to the research on the reception of the philosopher they refer to. The thus formulated question is all the more reasonable as such a scenario is realised in the case of a question of a relationship occurring between neo-kantianism and neo-hegelianism.

While analysing the problem of reception of Kant's philosophy in relation to the reception of Hegel's philosophy, Herbert Schnädelbach notes: "Firstly, a Hegelian party in the obvious understanding does not exist; secondly, not all of those who refer to Kant automatically become neo-Kantians. The second issue is as follows: the difference between an »-ian" and a »neo-ian « is that the starting point for a »neo-ian « rests in the impossibility of a direct continuation of the thought of the author he refers to; for him he becomes historical. Hence a »neo-ian« does not see any other option than to practise his thought in his "spirit". What distinguishes neo-kantianism from the Kantian movement of the second half of the nineteenth century, and also neo-hegelianism from Hegelianism proper, is - to introduce a certain order - the historical awareness, the experience of breaking the tradition in such a manner that the »a return 
to...! « stands a chance only as »a going beyond...! «. ${ }^{1}$ The period of renaissance of the classics - from Trendelenburg's neo-aristotelism to the neo-marxism of the $1920 \mathrm{~s}$ - is the time of historicism which, contrary to traditionalism wished to be modern, i.e. future-oriented due to historical education, which is mainly confirmed by its historical architecture. There is nothing more erroneous than the belief that neo-Kantians in fact wanted to be traditional Kantians; what they wanted was not only to be Kantians but also the "new « - independent (originäre) philosophers". ${ }^{2}$ However, this thesis is in conflict with what one of the representatives of neo-hegelianism, Richard Kroner, wrote in the Introduction to his opus vitae. "As Windelband once said: »to understand Kant means to go beyond him «; thus, we may say that understanding Hegel means absolutely not being able to go any further. However, if there should be something "post-Hegel «, then it is required to create a new beginning". ${ }^{3}$

We must first of all refer to the texts invoked by Schnädelbach, namely those by Windelband and Rickert. In the first place, he refers to a collection of texts by Windelband published in 1884, who in the preface dated for "October 1883" notes that: "All of us who practise philosophy in the nineteenth century are Kant's disciples. However, our today's "return " to him should not only constitute the renewal of a historically founded form in which he presents the idea of critical philosophy. The stronger the antagonism revealed between the various motives of his thinking is depicted, the more measures can we discover to discuss the problems which he created with his solutions to the problems. To understand Kant means to go beyond him [bolded by - AJN]". ${ }^{4}$ In the second case, Schnädelbach refers to the memoirs on Alois Riehl (27.05.1844 21.11.1924) by Heinrich Rickert, in which the founder of the great Baden

${ }^{1}$ In 1882 Wilhelm Windelband said: „To understand Kant means to go beyond him", and in 1924 Heirich Rickert, looking back at the history of neokantism, found that his representatives „,by returning to Kant significantly pushed scientific philosophy forward". As cited in: H. Holzhey: Neukantianismus. In: Historisches Wörterbuch der Philosophie. Bd. 6. Basel-Stuttgart 1984, col. 747 et seq. [note - H.S.]. It is necessary to add to Schnädelbach's note that the actual quote is as follows: „However, they are rightly called neo-Kantians as they have returned to Kant while, at the same time, significantly pushing scientific philosophy forward". H. Rickert: Alois Riehl. "Logos" 1924-25, Bd. 13, p. 164.

2 H. Schnädelbach: Nasz nowy neokantyzm. Trans. A.J. Noras. "Folia Philosophica". Ed. P. Łaciak. T. 24. Katowice 2006, pp. 15-16.

3 „Wenn Windelband einmal sagt: »Kant verstehen heißt über ihn hinausgehen", so könnte man auch sagen, Hegel verstehen heißt einsehen, daß über ihn schlechterdings nicht mehr hinausgegangen werden kann. Sollte es noch ein »Nach - Hegel « geben, so mußte ein neuer Anfang gemacht werden." R. Kroner: Von Kant bis Hegel. Bd. 1: Von der Vernunftkritik zur Naturphilosophie. Tübingen 1921, p. 6.

4 W. Windelband: Vorwort. In: Idem: Präludien. Aufsätze und Reden zur Einführung in die Philosophie. Bd. 1. 4. Aufl. Tübingen 1911, Bd. 1, p. IV. 
school enumerates the eminent neo-Kantians and concludes as follows: "However, they are rightly called neo-Kantians since, because they have returned to Kant, they significantly pushed scientific philosophy forward". ${ }^{5}$ Perhaps the thinkers indicated by Rickert as neo-Kantians are worth listing. These are: Otto Liebmann, Friedrich Albert Lange, Hermann Cohen, Wilhelm Windelband, and Paul Natorp, on whom he writes: "Certainly we cannot say that they were merely »Kantians «". ${ }^{6}$ For that reason, yet another question arises regarding the key that allows us to perceive them as genuine neo-Kantians. Whatever the perspective, it is yet another question concerning the understanding of neo-kantianism. Hence, it appears that an attempt to answer the questions on the relationship between neo-kantianism requires providing answers to several important questions, namely:

1. what is neo-kantianism?

2. what is neo-hegelianism?

3. what results from the relationship between them?

An attempt to define neo-kantianism is vulnerable to failure due to the complexity of the philosophical movement which, at the same time, tries to find the name for itself. All these difficulties were subject to numerous analyses; thus, there is no need to repeat them here. ${ }^{7}$ What deserves our attention is the fact that neo-kantianism does not stem from nowhere but constitutes an answer to a challenge faced by philosophy in the midnineteenth century when, on the one hand, the Hegelian idealism collapses and, on the other hand, the positivist-materialistic vision of reality begins to dominate. That is why Christian Krijnen is right when assessing the historical context of neo-kantianism he makes the following remark as: "Despite its name, neo-kantianism does not owe it only to the return to Kantian philosophy for the purpose of its determined continuation. Neo-kantianism was rather to simultaneously fulfil a polemic task: It had to speak against those positivist, scientific, historical tendencies as well as those originating from the philosophy of life which caused post-kantian idealism to lose its dominant position in the spiri-

5 „Aber sie werden mit Recht Neukantianer genannt, denn sie führten dadurch, daß sie auf Kant zurückgingen, die wissenschaftliche Philosophie zugleich erheblich vorwärts”. H. Rickert: Alois Riehl. „Logos“ 1924/25, Bd. 13, p. 164.

6 Ibidem.

7 Cf. A.J. Noras: Historia neokantyzmu. Katowice 2012, pp. 19-38. 
tual life of Germany shortly after Hegel's death". ${ }^{8}$ Neo-kantianism may no longer by its name constitute the renewal of Kant's philosophy in its historical form, although the problem per se is whether historical philosophy may be renewed to take on the same form as previously. The key is in the term used by Janina Kiersnowska-Suchorzewska claiming that the multiplicity of directions in neo-kantianism results from the fact that "his [Kant's - AJN] legacy left to his numerous heirs was once again scattered: each received or, more precisely, seized a part of it - and treats it as pars pro toto. This is where the divergence of interpretations in neo-kantian theories originates". 9 The said "pars pro toto" is crucial as it directly results in the multiplicity of directions. A noteworthy, although quite a concise interpretation of neo-kantianism, is proposed by Richard Müller-Freienfels (1882-1949), who analyses the most important philosophical trends of the beginning of the twentieth century. "In the concept of »neo-kantianism « - as he writes on neo-kantians' attitude to Kant - which contains all these pursuits, stress should be made on »neo" and not on Kantianism, albeit its representatives, at least firstly, also highlighted the second part of the term". ${ }^{10}$ This remark which, to the same extent, may refer to the representatives of neo-hegelianism, shows that the matter of a relationship between the thinkers emphasising the return and renewal of previous philosophy to the philosopher that they refer to is not at all explicit, as we need to immediately reject the belief that it is possible to reach the views of some mythical real author. Obviously, such a stance must meet with the criticism of representatives of hermeneutics who claimed that an author may be understood better than he understands himself. Indeed, the problem consists in the fact that "better understanding" is simply the consequence of having deeper knowledge of the historical context in which the author needs to be considered. The author does not know the context as well as a person who takes a retrospective glance at a particular philosophy. However, what appears here for the very first time is the term "historical context" which immediately enmeshes a researcher in certain aporias.

Undeniably, the problem of hermeneutics is complex; however, it clearly communicates the issue to which Eggert Winter refers as "hermeneutic fundamental aporia"11 and depicts on Cohen's example. In the

8 Ch. Krijnen: Hegel und der Neukantianismus. Eine systemphilosophische Konfrontation. In: Hegel und die Geschichte der Philosophie. Hrsg. von D.H. Heidemann, Ch. Krijnen. Darmstadt 2007, p. 240.

9 J. Kiersnowska-Suchorzewska: Metafizyka Kanta w świetle polemiki neokantystów. „Przegląd Filozoficzny” 1937, no. 40, p. 367.

10 R. Müller-Freienfels: Die Philosophie des 20. Jahrhunderts in ihren Hauptströmungen. Berlin 1923, p. 13.

11 E. Winter: Ethik und Rechtswissenschaft. Eine historisch-systematische Untersuchung zur Ethik-Konzeption des Marburger Neukantianismus im Werke Hermann Cohens. Berlin 1980, p. 96. 
conclusion to his article dedicated to the controversies between Friedrich Adolf Trendelenburg and Kunon Fischer, the founder of the Marburg School writes: "The levers of what belongs to the future are also the touchstone of what belongs to the past. A historical connection with what belongs to the past can be established only - and historical knowledge of what belongs to the past opens only - in what is new within the old. With what is new we become internally united; in what is new we must participate as advocates of the truth if we are to succeed in creating the real history". ${ }^{12}$ According to Winter, the aporia is that on the one hand we have the knowledge of the old contained in what is new, whereas on the other, that it happens without "bringing what is new into what is old". ${ }^{13}$ For this reason, Cohen speaks of two things that we must not forget, namely that we should not mix the old with the new. However, we tend to forget about these principles, as does hermeneutics which fails to differentiate between them. As to understand a particular author better than he understood himself means to understand through the prism of what is new.

Thus, when Müller-Freienfels analyses the situation of neo-kantianism in his short reasoning, he notes: "To a retrospectively looking observer it should be amusing to see how all those shrewd thinkers who set out to find pure Kant with all their shrewdness in fact interpreted themselves into Kant (hineininterpretierten) and exactly by doing so they document his philosophical meaning" ${ }^{14}$ The artificially coined phrase "to interpret oneself into something" means nothing else but that these philosophers adjusted their understanding of philosophy to the philosophy of Kant. In other words, this means that they found Kant because they found themselves. This fact is very clearly stressed by Hermann Cohen, who notes: "It is impossible to pass a judgement on Kant without exposing in every verse what kind of world one carries in his head..$^{15}$ Thus, he emphasises only that everyone reads Kant in their own way. And the sine qua non condition for the interpretation of the philosopher to whom a given philosopher refers is that in his doctrine he finds elements of that doctrine. Therefore, the condition of adjusting one's concept to an old one consists in finding the elements that were not there. An interpretation is not as much reading anew as reading the new. The new mainly results from the historical context. Hans Wagner (1917-2000), who in his

12 H. Cohen: Zur Controverse zwischen Trendelenburg und Kuno Fischer. "Zeitschrift für Völkerpsychologie und Sprachwissenschaft". Hrsg. von M. Lazarus, H. Steinthal. Berlin 1871, Bd. 7, p. 296.

13 E. Winter: Ethik und Rechtswissenschaft..., p. 96. Cf. H. Cohen: Zur Controverse zwischen Trendelenburg und Kuno Fischer..., p. 293.

14 R. Müller-Freienfels: Die Philosophie des 20. Jahrhunderts in ihren Hauptströmungen..., p. 13.

15 H. Cohen: Kantowska teoria doświadczenia. Trans. A.J. Noras. Kęty 2012, p. 30. 
analyses of science in the light of history emphasises the fact of the existence of historical and non-historical sciences and makes an attempt to demonstrate the problem of the said context. However, at the same time, he remains convinced that non-historical sciences, for instance physics, also have a history that they unconditionally need to refer to. Hence, Wagner believes it is necessary to explain three things if one wishes to achieve "a philosophical concept of historical understanding and an insight into the theoretically principled (prinzipientheoretische) possibility of historical understanding" ${ }^{16}$ Wagner is convinced that it is required to perform:

1. a more accurate examination of an object of historical understanding with its methodological specificity,

2. a more accurate examination of the theorem of the so-called hermeneutic circle,

3. a more accurate examination of the internal structure of the relation between interpretation and understanding and enhance these considerations with the question of the possibility of internal and validating progressivism (geltungsmäßigen Progressivität) of historical understanding, i.e. establish whether historical understanding is at all possible.

Wagner is a transcendentalist, who, while being ontologically-oriented (the aftermath of his interest in Nicolai Hartmann's philosophy), takes up the problem of hermeneutics by adopting a systematic perspective and in the light of the problematique of the final establishment characteristic also for neo-kantianism. The key to understanding the history of philosophy is indeed found in the attempt to answer Kant's question: how is historical understanding achieved? And, at the same time, it is revealed that the response given by representatives of hermeneutics is not satisfactory as it fails to consider all the circumstances which affect historical understanding. Indeed, for historical understanding, it is necessary to expressly separate what is given by the author from what was added by an interpreter. Hermeneutics does not attempt to answer the thus formulated question; it does not even attempt to raise it. The assumption that revealing a broader context will help to better understand an author is not necessarily true since it is based on learning what is new.

In reference to what has been said so far, Richard Müller-Freienfels characterised neo-kantianism in the following way: "As a result of that, the vague term "neo-kantianism « also does not define a uniform school but constitutes a collective definition of very different directions with one

16 H. Wagner: Philosophie und Reflexion. 2. Aufl. München-Basel 1967, p. 389. 
common thing only - that they speak in the Kantian language" ${ }^{\prime 17}$ Therefore, the concept of neo-kantianism according to Müller-Freienfels's thesis is a "vague" and "collective definition" rather than a school. This is confirmed by a Danish philosopher, Harald Höffding (1843-1931), an author of the history of modern philosophy translated into German in the years 1895-1896, who writes: "That is why the so-called neo-kantianism does not define a closed school but rather a pursuit (Bestreben) towards epistemological verification of the terms used. As opposed to the philosophy of romanticism, a lot from Kant's study was captured by positivism".$^{18}$ In principle, this remains consistent with the conviction expressed by Ernst von Aster who, in his analyses of neo-kantianism, reduces it to two schools, namely the Baden and the Marburg school. ${ }^{19}$ And by doing so, von Aster does not acknowledge the existence of the so-called neokantism, whose characteristic feature is Kantian philosophy, and thereby rejects the attempt at "literal" understanding of Kant's philosophy.

Willy Moog (1888-1935) speaks of "neo-kantians proper" when he writes: "Neo-kantians proper sought systematic refreshment of Kant's teachings and liberating his cognitive theories from psychological and metaphysical remains".$^{20}$ This means that it is difficult to search for an orthodoxy here, which Paul Natorp explains as follows in his flagship text: "Speaking of an orthodox Kantianism of the Marburg school was never well-founded and along with further development of the school it lost even the faintest pretence of justification. It is true that, in his three fundamental works devoted to the interpretation of Kant, Hermann Cohen insisted on explaining the literary sense of the Kantian theorems ( $S \ddot{a}-$ $\mathrm{te}$ ) and understanding him on the basis of his own authentic, text-based (urkundlich), vital thoughts before it is possible to make an effort to go beyond Kant". ${ }^{21}$ And again, the theme characteristic of neo-kantianism appears, namely, the suggestion of going beyond Kant.

From what has been said thus far, a slightly obscure portrait of neo-kantianism emerges which, however, still enables us to point out significant traits of its characterisation which may serve to indicate the differences between neo-kantianism and neo-hegelianism in order to de-

17 R. Müller-Freienfels: Die Philosophie des 20. Jahrhunderts in ihren Hauptströmungen.

18 H. Höffding: Geschichte der neueren Philosophie. Eine Darstellung der Geschichte der Philosophie von dem Ende des Renaissance bis zu unseren Tagen. Bd. 2. Übers. von F. Bendixen. Leipzig 1896, p. 616.

19 Cf. E. von Aster: Die Philosophie der Gegenwart. Leiden 1935, pp. 4-53.

20 W. Moog: Die deutsche Philosophie des 20. Jahrhunderts in ihren Hauptrichtungen und ihren Grundproblemen. Stuttgart 1922, p. 181.

21 P. Natorp: Kant a szkoła marburska. Trans. A.J. Noras. in: Neokantyzm badeński i marburski. Antologia tekstów. Ed. A.J. Noras, T. Kubalica. Katowice 2011, p. 241. 
termine whether it makes sense to speak of neo-philosophy at all. As indeed it appears to be misplaced, since if there existed an apriori possibility to define the relationship between philosophy and its renewed version, between philosophy and its neo-philosophy, in the first place it would be necessary to inquire about the sense of existence of neo-philosophy. If each of them constituted a mere renewal of a historical thought it would probably be pointless. Therefore, it is required to consider two elements, namely, the assumption that neo-philosophy deserves our attention only because it is more than the philosophy it refers to. Therefore, neo-philosophy has a certain "addition" in the form of the specificity of the person who interprets philosophy, as an interpretation constitutes a complementation, which raises certain doubts in the light of Richard Kroner's remark, who - as it was already cited - stated: "As Windelband once said: "to understand Kant means to go beyond him «, thus we may say that to understand Hegel means absolutely not to be able to go any further". ${ }^{22}$ However, the incapability to go beyond Hegel would mean an ideally constructed neo-philosophy - such that only recalls a particular philosopher.

The question that arises in relation to Kroner's comment is as follows: if it is impossible to go beyond Hegel, does it make sense to renew his philosophy? Is it not true that we should rather treat it as a historical phenomenon and refer to it only in this context?

However, we need to go back to neo-kantianism and indicate its important elements, namely:

a) neo-kantianism means "going beyond" - as Schnädelbach puts it, and only then it is possible. When the "going beyond" does not occur, what we deal with is "Kantian philology", i.e.

b) "going beyond" is based on methodological lawlessness and boils down to the methodological principle formulated by Janina Kiersnowska-Suchorzewska which, on the other hand, comes down to the "par pro toto" formula,

c) "going beyond" is therefore equivalent with the absence of orthodoxy - a subject already taken up by Natorp who in the article Kant and the Marburg School expressly states that: "Speaking of an orthodox Kantianism of the Marburg school was never wellfounded and along with further development of the school it lost even the faintest pretence of justification", ${ }^{23}$

d) the absence of orthodoxy results from the neo-kantians' intention. What they mean does not consist in reading the problem in the light of Kant's philosophy - this is what the problem of neo-

22 R. Kroner: Von Kant bis Hegel. Bd. 1..., p. 6.

23 P. Natorp: Kant a szkoła marburska..., p. 241. 
philosophy is often brought down to, but rather in using Kant's philosophy to solve the problems faced by philosophy,

e) this is confirmed by Gerd Wolandt with regard to three "Kantian" works by Hermann Cohen, who states that the founders of the Marburg school did not speak of "[...] »historical Kant« but of a new systematisation of Kantian measures" 24 ,

f) we may probably point to a number of Cohen's critics - and presumably many of them would be neo-kantians - who took up the problem of "orthodoxy". A classic example in relation to Cohen may be Julius Ebbinghaus (1885-1981),

g) neo-kantianism - at least it seems that way - possesses an analogy at a time approximated to its own, and it is not neo-positivism. Thus, we may conclude that not every neo-philosophy constitutes a renewal, restoration, invocation, and a tuned-up version of old philosophy.

II

Neo-hegelianism is not as much a negation of neo-kantianism as it is a development of the thinker's philosophy constituting a model, i.e. Hegel; however, the said development is conducted towards a slightly different direction. It is worth adding at this point that the term "neohegelianism" (Neuhegelianismus) was allegedly coined by Fritz Berolzheimer (1869-1920), who highlights that Hegel understands history in the context of developmental tendencies and concludes: "That is why we reached for $\mathrm{H}$ e gel who depicted law in its developmental character and recognised history as the development of ideas. In this sense, we are $\mathrm{n}$ e $\mathrm{o}-\mathrm{h}$ e $\mathrm{g}$ e $\mathrm{l}$ i a $\mathrm{n} \mathrm{s}$ ". ${ }^{25} \mathrm{It}$ is also worth recalling the already quoted thought of Richard Kroner who points to two issues: (1) the incapability to go beyond Hegel and (2) the necessity to find a new beginning. ${ }^{26} \mathrm{How}-$ ever, it may be perfidiously stressed that the thinker who meets the conditions laid down by Kroner is no-one else but Martin Heidegger. This is due to the fact that in the lecture from 1964 entitled The End of Philosophy and the Task of Thinking, Heidegger raises two questions:

24 G. Wolandt: Einleitung. In: H. Cohen: Werke. Bd. 8: System der Philosophie. 3. Teil: Ästhetik des reinen Gefühls. Erster Band. Hildesheim-Zürich-New York 2005, p. X*.

25 F. Berolzheimer: Das Programm des Neuhegelianismus. "Archiv für Rechts- und Wirtschaftsphilosophie" 1913, Jg. 7, p. 508.

26 Cf. R. Kroner: Von Kant bis Hegel. Bd. 1: Von der Vernunftkritik zur Naturphilosophie. Tübingen 1921, p. 6. 
"1. To what extent does philosophy end today?

2. What is the task of thinking at the end of philosophy?". ${ }^{27}$

However, the absurdity of this thesis rests in the fact that it would never cross anyone's mind to perceive Heidegger as a representative of neo-hegelianism. Thus, is Kroner's thesis false? By no means, only the range of its impact should be limited to earlier times. Moreover, Helmut Holzhey ${ }^{28}$ points out that the term "neo-hegelianism" originates from a book by Wilhelm Tobias devoted to the limits of cognition, and in fact, Tobias speaks of "bold neo-hegelianism" in reference to the concept created by Wilhelm Wundt (1832-1920) and John Tyndall (1820-1893). ${ }^{29}$ At the same time, the researchers of neo-hegelianism unanimously point out the fact that it did not transform into a school. "A characteristic feature of German neo-hegelianism - as Heinrich Kleiner states in this spirit - is that from the increasingly intensely shaped debate with Hegel only insignificant directives resulted, those regarding the systematic transformation, further development or conversion of Hegel's philosophy. Thereby, Heglism was incapable of founding a school of a form comparable to neo-hegelianism". ${ }^{30} \mathrm{He}$ is accompanied by Peter Hoeres, who observes: "The formation of a school, as it was the case with neoKantians, was what neo-Hegelians failed to achieve, although Hermann Glockner (1896-1979) seeks a parallel depiction of the phases of development of neo-kantianism and neo-hegelianism in the scheme comprising three phases - philology, prospective presentation, own establishment of a system". ${ }^{31}$

The problem becomes complicated here for two related reasons. First of all, because the situation of philosophy after Kant's death is different as compared with that following Hegel's death. This is pointedly explained by Herbert Schnädelbach; hence, it is worth quoting a longer passage which opens his article devoted to new neo-kantianism:

"When in the jubilee year of 1981 the Stuttgart Hegel Congress devoted to the issue Kant of Hegel? was held, to some this question might have sounded like a pseudo-alternative. Unfortunately, no questionnaire

${ }_{27}$ M. Heidegger: Koniec filozofii i zadanie myślenia. Trans. K. Michalski. In: M. Heidegger: Ku rzeczy myślenia. Trans. K. Michalski, J. Mizera, C. Wodziński. Warsaw 1999 , p. 77.

${ }_{28}$ Cf. H. Holzhey: Neukantianismus. In: Historisches Wörterbuch der Philosophie. Bd. 6: Mo-O. Hrsg. von J. Ritter, K. Gründer. Basel 1984, p. 748.

29 W. Tobias: Grenzen der Philosophie: constatirt Riemann und Helmholtz, vertheidigt gegen von Hartmann und Lasker. Berlin 1875, p. 37.

30 H. Kleiner: Neuhegelianismus. In: Historisches Wörterbuch der Philosophie. Bd. 6..., p. 743.

31 P. Hoeres: Krieg der Philosophen. Die deutsche und die britische Philosophie im Ersten Weltkrieg. Paderborn 2004, pp. 61-62. 
was distributed then in relation to this question, however, we can be certain that when given such a choice over ninety percent of those who currently practise philosophy would have responded: »Kant, naturally!« Who else still wants to be a Hegelian today? Many interpret Hegel - meticulously and persistently, but their readiness to also argument his philosophy usually remains on hold; their fixation on Hegel is then mysterious. With Kant the situation is completely different; if researchers do not see themselves as historians of philosophy, they are researchers and interpreters of Kant's philosophy, and, by principle, also Kantians; i.e. their historical and systematic interests are headed in the same direction. After all, Kant's philosophical authority is currently irrefutable, or so it seems, thus if we were to decide »Kant or Hegel? « we would all stand behind Kant. Does it then mean that because of this we are all Kantians or neo-Kantians?". 32

Secondly, it is worth pointing out the fact that contrary to neo-kantianism which slowly developed in philosophy, hegelianism managed to immediately develop a school founded by Hegel's first followers, namely scholars such as Philipp Konrad Marheineke (1780-1846), Eduard Gans (1798-1839), or Karl Ludwig Michelet (1801-1893). It is also significant that, right at the beginning, a dispute occurred among Hegelians, thus leading to the establishment of the Hegelian right and left wing, which - as it is commonly known - was a reaction to the work published in 1835 by Dawid Friedrich Strauß (1808-1874) Das Leben Jesu. ${ }^{33}$ Hence, we may risk a thesis that already after Hegel's death hegelianism developed these forms of reception which became the neo-Kantians' share only since 1865 .

However, this does not solve the problem of neo-hegelianism as the already mentioned Peter Hoeres points at Erich Kaufmann (1880-1972) as a thinker whose "neo-kantianism and neo-hegelianism no longer appear as a continuation of the plot but as hostile philosophies". ${ }^{34} \mathrm{~A}$ prime example is Kaufmann's criticism of neo-kantian philosophy of law as a follower of the Baden school. ${ }^{35}$ The hostility visible in Kaufmann slowly becomes the call sign of neo-hegelianism, and its beginnings may be sought already in the student of Wilhelm Dilthey, Ferdinand Jakob Schmidt (1860-1939) who in 1908 introduced a division in neo-kantianism and started to speak of old-Kantians, pseudo-Kantians, and neoKantians. Schmidt sees a problem in the fact that old-Kantians are not

32 H. Schnädelbach: Nasz nowy neokantyzm..., p. 15.

33 Cf. A.J. Noras: Kant i Hegel w sporach filozoficznych osiemnastego i dziewiętnastego. Katowice 2007, pp. 136-138.

34 P. Hoeres: Krieg der Philosophen..., p. 61.

35 E. Kaufmann: Kritik der neukantischen Rechtsphilosophie. Eine Betrachtung über die Beziehungen zwischen Philosophie und Rechtswissenschaft. Tübingen 1921. 
recognised by neo-kantianism although, in fact, among neo-Kantians he recognises philosophers who are not necessarily connected with broadly understood neokantism. These are Rudolf Haym, Eduard Zeller, Kuno Fischer, and Otto Liebmann. ${ }^{36}$ Moreover, Schmidt perceives neo-kantianism as a pseudo-doctricism.

The problem of neo-hegelianism is that in contrast to neo-kantianism it did not develop in the form of a school, which is connected with the division visible at its core. Wolfgang Schild depicts this ambivalence in reference to the neo-hegelianism of Josef Kohler (1849-1919), a lawyer and professor of the University of Berlin. The idea that is a key to understanding Kohler's neo-hegelianism in relation to previous philosophy is as follows: "For his philosophising still means (also) a discussion with particular philosophers of the past, a critical acquisition of foreign past thoughts, and so also using previous recognitions whose truth survived throughout the history". ${ }^{37}$ This is also the sense of a continuous discussion of philosophical problems, that is a constant work on persistently undertaken problems. The only advantage is that we do not need to begin $a b$ ovo each time. Indeed, the problem lies in the fact that referring to previous philosophy is not always connected with progress. This is how Schild expresses this idea in relation to Kohler as he tries to indicate that we cannot speak here of a simple interrelation. This is the thesis by Schild evaluating Kohler's neo-hegelianism, who emphasises that "the adoption of Hegelian philosophy as a whole would mean a regression". ${ }^{38}$ At the same time, one more important issue is revealed in Schild's considerations, namely the insufficiency of modern philosophy.

Schild refers to the thesis by Fritz Berolzheimer, who straightforwardly writes: "J. Kohler [...] is a neo-Hegelian". ${ }^{39}$ In Schild's view it is all the more important that Kohler seeks the "enemies" of philosophy and finds them in historicism, positivism, the neo-kantian philosophy of law and, finally, in the theory of the law of nature with variable content identifiable with the Marburg school of Rudolf Stammler (1856-1938). What is more, Schild is convinced of legitimacy of the stance represented by Kohler. Neither historicism nor positivism raise doubts as positions that cannot be maintained. However, the question of understanding the

36 F.J. Schmidt: Kant-Orthodoxie. In: Idem: Zur Wiedergeburt des Idealismus. Philosophische Studien. Leipzig 1908, p. 226.

37 W. Schild: Die Ambivalenz einer Neo-Philosophie. Zu Josef Kohlers Neuhegelianismus. In: Deutsche Rechts- und Sozialphilosophie um 1900. Zugleich ein Beitrag zur Gründungsgeschichte der internationalen Vereinigung für Rechts- und Sozialphilosophie (IVR). In Verbindung mit Konrad Cramer, Ralf Dreier und Werner Maihofer herausgegeben von Gerhard Sprenger. Stuttgart 1991, p. 46.

38 Ibidem, p. 47.

39 F. Berolzheimer: System der Rechts- und Wirtschaftsphilosophie. Bd. 2: Die Kulturstufen der Rechts- und Wirtschaftsphilosophie. München 1905, p. 439. 
neo-kantian philosophy of law is not unambiguous; therefore, Schild's declaration may be interpreted as an explicit proof of his determinedness. Yet, we need to admit that he is right when it comes to his evaluation of Kohler's position, whose neo-hegelianism is incomprehensible to Schild. And it is such since Schild writes the following as he evaluates his stance: "As a matter of fact, Kohler formulated his result already in 1883: »What remains from hegelianism are the great ideas of world development and the idea of unity in multiplicity «. Generally speaking, however, he saw Hegel's philosophy as overcome". ${ }^{40}$ Nonetheless, later Kohler changed his stance regarding the evaluation of Hegel's philosophy and sided with neo-Hegelians.

III

Therefore, what results from this short presentation of neo-kantianism and neo-hegelianism?

Firstly, the conviction that the term "neo-philosophy" says nothing about the kind of the presented philosophy and merely constitutes information that we might seek in it a certain pattern from the past. Nonetheless, these patterns are to a smaller or greater extent present in "neo-philosophy". The neo-kantianism of the Marburg school is neo-kantianism because it is unorthodox, whereas the neo-kantianism of the so-called Kantian philology representatives fails to fulfil this condition.

Secondly, we have the related awareness of possible differences within "neo-philosophy". If we were to ask about the uniformity of neophilosophy, it would emerge that to the greatest extent it is concerned with neo-positivism. Still, it is difficult to speak of uniformity in the case of neo-kantianism, neo-hegelianism or neo-tomism, which however tends to be omitted in considerations.

Thirdly, it is absolutely necessary to revise the view that neo-philosophy stems from a lack of knowledge and understanding of philosophical problems. By the way, this thesis is eagerly repeated by supporters of the history of philosophy understood as an auxiliary science of philosophy (whatever is meant by this). On the contrary, neo-philosophy means an acknowledgement of the richness of thoughts of the philosophy of the past.

40 W. Windelband: Die Ambivalenz einer Neo-Philosophie..., p. 64. 


\section{Bibliography}

Aster E., Die Philosophie der Gegenwart. Leiden 1935.

Berolzheimer F., Das Programm des Neuhegelianismus. „Archiv für Rechtsund Wirtschaftsphilosophie“ 1913, Jg. 7.

Berolzheimer F., System der Rechts- und Wirtschaftsphilosophie. Bd. 2: Die Kulturstufen der Rechts- und Wirtschaftsphilosophie. München 1905.

Cohen H., Kantowska teoria doświadczenia. Trans. A.J. Noras. Kęty 2012.

Cohen H., Zur Controverse zwischen Trendelenburg und Kuno Fischer. "Zeitschrift für Völkerpsychologie und Sprachwissenschaft". Hrsg. von M. Lazarus, H. Steinthal. Berlin 1871, Bd. 7.

Heidegger M., Koniec filozofii $i$ zadanie myślenia. Trans. K. Michalski. In: M. Heidegger: Ku rzeczy myślenia. Trans. K. Michalski, J. Mizera, C. Wodziński. Warsaw 1999.

Hoeres P., Krieg der Philosophen. Die deutsche und die britische Philosophie im Ersten Weltkrieg. Paderborn 2004.

Höffding H., Geschichte der neueren Philosophie. Eine Darstellung der Geschichte der Philosophie von dem Ende des Renaissance bis zu unseren Tagen. Bd. 2. Übers. von F. Bendixen. Leipzig 1896.

Holzhey H., Neukantianismus. In: Historisches Wörterbuch der Philosophie. Bd. 6. Basel-Stuttgart 1984, col. 747 et seq.

Holzhey H., Neukantianismus. In: Historisches Wörterbuch der Philosophie. Bd. 6: Mo-O. Hrsg. von J. Ritter, K. Gründer. Basel 1984.

Kaufmann E., Kritik der neukantischen Rechtsphilosophie. Eine Betrachtung über die Beziehungen zwischen Philosophie und Rechtswissenschaft. Tübingen 1921.

Kiersnowska-Suchorzewska J., Metafizyka Kanta w świetle polemiki neokantystów. „Przegląd Filozoficzny” 1937, no. 40.

Krijnen Ch., Hegel und der Neukantianismus. Eine systemphilosophische Konfrontation. In: Hegel und die Geschichte der Philosophie. Hrsg. von D.H. Heidemann, Ch. Krijnen. Darmstadt 2007.

Kroner R., Von Kant bis Hegel. Bd. 1: Von der Vernunftkritik zur Naturphilosophie. Tübingen 1921.

Moog W., Die deutsche Philosophie des 20. Jahrhunderts in ihren Hauptrichtungen und ihren Grundproblemen. Stuttgart 1922.

Müller-Freienfels R., Die Philosophie des 20. Jahrhunderts in ihren Hauptströmungen. Berlin 1923.

Natorp P., Kant a szkoła marburska. Trans. A.J. Noras. in: Neokantyzm badeński i marburski. Antologia tekstów. Ed. A.J. Noras, T. Kubalica. Katowice 2011.

Noras A.J., Historia neokantyzmu. Katowice 2012.

Noras A.J., Kant i Hegel w sporach filozoficznych osiemnastego i dziewiętnastego. Katowice 2007.

Rickert H., Alois Riehl. „Logos" 1924-25, Bd. 13.

Schild W., Die Ambivalenz einer Neo-Philosophie. Zu Josef Kohlers Neuhegelianismus. In: Deutsche Rechts- und Sozialphilosophie um 1900. Zugleich ein Beitrag zur Gründungsgeschichte der internationalen Vereinigung für Rechts- und So- 
zialphilosophie (IVR). In Verbindung mit Konrad Cramer, Ralf Dreier und Werner Maihofer herausgegeben von Gerhard Sprenger. Stuttgart 1991. Schmidt F.J., Kant-Orthodoxie. In: Idem: Zur Wiedergeburt des Idealismus. Philosophische Studien. Leipzig 1908.

Schnädelbach H., Nasz nowy neokantyzm. Trans. A.J. Noras. „Folia Philosophica". Ed. P. Łaciak. T. 24. Katowice 2006.

Tobias W., Grenzen der Philosophie: constatirt Riemann und Helmholtz, vertheidigt gegen von Hartmann und Lasker. Berlin 1875.

Wagner H., Philosophie und Reflexion. 2. Aufl. München-Basel 1967.

Windelband W., Vorwort. In: Idem: Präludien. Aufsätze und Reden zur Einführung in die Philosophie. Bd. 1. 4. Aufl. Tübingen 1911, Bd. 1.

Winter E., Ethik und Rechtswissenschaft. Eine historisch-systematische Untersuchung zur Ethik-Konzeption des Marburger Neukantianismus im Werke Hermann Cohens. Berlin 1980.

Wolandt G., Einleitung. In: H. Cohen: Werke. Bd. 8: System der Philosophie. 3. Teil: Ästhetik des reinen Gefühls. Erster Band. Hildesheim-Zürich-New York 2005.

\section{Summary}

\section{Neo-kantianism and Neo-hegelianism. Comments on Neo-philosophy}

The article addresses the problem of neo-philosophy in the light of its relation to philosophy while constituting its renewal. The subject matter of the reflection is the analysis of neo-kantianism and neo-hegelianism, whereas the result of the conducted analyses is a conviction that it is not possible to speak of a simple analogy between philosophy and neo-philosophy which relates to it. Even if this analogy were possible in the case of neo-hegalianism, certainly such a situation cannot and does not occur in the case of neo-kantianism. The latter is characterised by a lack of orthodoxy in relation to Kant's philosophy which in fact is its characteristic feature.

\section{Keywords}

neo-kantianism, neo-hegelianism, Marburg school, Baden school 